\title{
Christmas Disease in One of a Pair of Monozygotic Twin Girls, Possibly the Effect of Lyonization
}

\author{
THOMAS RÉVÉSZ, DEZSÖ SCHULER, BÉLA GOLDSCHMIDT, and \\ SUSAN ELÖDI
}

\author{
Second Department of Paediatrics, Semmelweis University Medical School and Central Institute of Haematology \\ and Blood Transfusion, Budapest, Hungary
}

Christmas disease (clotting factor IX deficiency) being, like haemophilia (factor VIII deficiency), a rare $\mathrm{X}$-linked recessive character is very seldom found in females. A case is reported here of a young girl who suffers from Christmas disease but whose monozygotic twin sister does not.

\section{Case Report}

The proposita, a girl of 18 months, was sent to our department in May 1970 from Jászberény County Hospital. She had been admitted previously on 2 occasions to the hospital for excessively severe bleeding following minor trauma. She was in severe shock both times and required multiple transfusions. After the 2nd episode she was transferred to us for further investigations. Her parents said that she always bruised easily after slight injury and developed sizeable swellings. There had been bleeding from the nose and gums on a few occasions. A swelling of the elbow joint was noted once, but it subsided spontaneously after a couple of weeks.

We found her to be of average build and development. Several bruises were seen on her arms and legs. Her blood count was normal, without any gross anaemia present, probably as a result of her recent transfusions. There was no indication of organic disease on physical examination. No abnormality was found in the chest or abdomen. Musculature was adequately developed, joints appeared to be of normal shape and movements were unlimited in all extremities. She was a somewhat shy, but intelligent little girl.

\section{Family History}

The pedigree of the family is given in Fig. 1. On taking the family history, we could not trace a single relative or progenitor with bleeding episodes or with a tendency to easy bruising. There was information about the last 5 generations but no indication of any consanguinous marriage.

Of particular interest is the fact that the proposita (III.3) has a twin sister (III.4) who proved to be mono- zygotic. The twin sister has never shown any tendency to bleeding, nor does she bruise easily after falls or small injuries. The father (II.3), a blacksmith by profession, appeared to be healthy and completely free of bleeding symptoms, as did the mother (II.4), grandmother (I.4), and other members of the family who were investigated. Neither the mother nor the grandmother had ever experienced unusually long or severe menstruations.

\section{Methods}

Coagulation Studies. Whole blood clotting time was determined in glass tubes by the method of Lee and White (1913). The bleeding time was measured according to Duke. The platelets were counted in the phase contrast microscope as described by Brecher and Cronkite (1950/1951). Adhesiveness of platelets in vitro was studied with Hellem's technique (1960). Prothrombin time was measured by Quick's method, kaolinactivated partial thromboplastin time (PTT) was carried out according to the method described by Proctor and Rapaport (1961). The thromboplastin generation test was performed by the method of Biggs and Douglas (1953). Quantitative determination of factor IX activity was performed by means of kaolin-activated PTT, based principally on the method of Langdell, Wagner, and Brinkhous (1953). Factor IX deficient plasma served as substrate plasma in this assay.

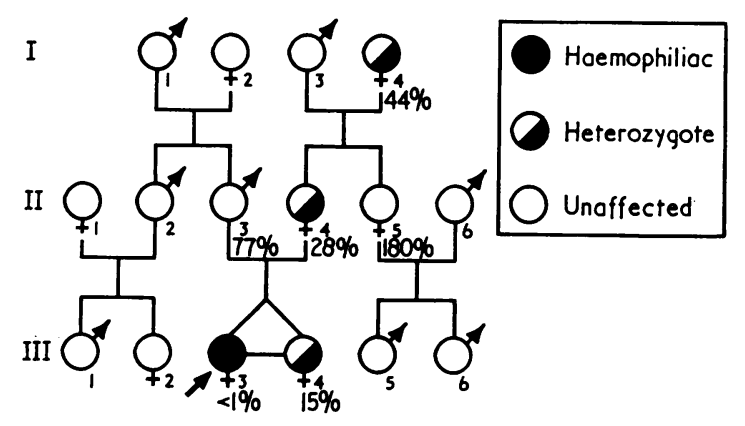

FIG. 1 
HL-A Typing was carried out using the standard NIH microlymphocytotoxicity test.

Mixed Lymphocyte Cultures were performed according to the method of Schellekens and Eujsvoogel (1968).

Glucose-6-phosphate Dehydrogenase was measured in the blood of the twins by the spectrophotometric method of Marks and Gross (1959).

Chromosome Studies were performed in the leucocyte cultures using the method of Moorhead et al (1960). On one occasion the fluorescent pattern of the chromosomes was also studied by a modified version of Caspersson's method (Caspersson et al, 1968).

\section{Results}

Zygosity of the Twins. We observed a striking resemblance between the patient and her twin sister. They both have fair hair, blue eyes, and similarly shaped heads, noses, and ears. Their heights were the same on all occasions, but the proposita was usually a little under-weight. It was in fact extremely difficult to tell which was which, except for the bruises on the girl with Christmas disease.

Unfortunately no information was available about the placenta or the amniotic sac. Detailed analysis of red cell groups, serum groups, and isozymes showed the twins to be identical for these characters, and to conform with those of their parents (Table I).

The twins' fingerprints showed a striking resemblance in ridges and angles. The atd angles, for example, were equal on the corresponding hands of the twins. The difference between the total ridge counts was 8 .

TABLE I

BLOOD GROUP STUDIES OF THE FAMILY

\begin{tabular}{|c|c|c|c|c|}
\hline \multirow{2}{*}{$\begin{array}{l}\text { Blood Group } \\
\text { System }\end{array}$} & \multicolumn{4}{|c|}{ Type } \\
\hline & Father & Mother & Proposita & Sister \\
\hline $\begin{array}{l}\text { ABO } \\
\text { Rh } \\
\text { MNSs } \\
\text { P1 }_{1} \\
\text { Lutheran } \\
\text { Kell } \\
\text { Lewis } \\
\text { Duffy } \\
\text { Kidd } \\
\text { Xg } \\
\text { Dombrock } \\
\text { PGM } \\
\text { ADA } \\
\text { Gc } \\
\text { Hp } \\
\text { Gm } \\
\text { InV } 1\end{array}$ & $\begin{array}{l}A_{1} \\
R_{1} R_{2} \\
M N S s \\
+ \\
a-b+ \\
- \\
a+b- \\
a+b+ \\
a-b+ \\
a+ \\
a- \\
1 \\
1 \\
2-1 \\
2-2 \\
a-x-b+ \\
-\end{array}$ & $\begin{array}{l}O \\
R_{2} R_{2} \\
\text { MNSs } \\
+ \\
a-b+ \\
- \\
a-b- \\
a+b+ \\
a+b+ \\
a+ \\
a- \\
2-1 \\
2-1 \\
1 \\
2-2 \\
a-x-b+ \\
-\end{array}$ & $\begin{array}{l}A_{1} \\
R_{1} R_{2} \\
M N S s \\
+ \\
a-b+ \\
- \\
a+b- \\
a+b+ \\
a-b+ \\
a+ \\
a- \\
1 \\
2-1 \\
2-1 \\
2-2 \\
a-x-b+ \\
-\end{array}$ & $\begin{array}{l}A_{1} \\
R_{1} R_{2} \\
M N S s \\
+ \\
a-b+ \\
- \\
a+b- \\
a+b+ \\
a-b+ \\
a+ \\
a- \\
1 \\
2-1 \\
2-1 \\
2-2 \\
a-x-b+ \\
-\end{array}$ \\
\hline
\end{tabular}

On the basis of the above findings, using the method of Maynard Smith and Penrose (1954/ 1955), we calculated the total chance of the twins being dizygotic as 0.0006 and of being monozygotic as 0.9994 (Table II).

HL-A typing also showed complete identity between the girls, and as both parents were also tested,

TABLE II

CALCULATED RELATIVE CHANCES OF THE TWINS BEING DIZYGOTIC

\begin{tabular}{l|c}
\hline \multicolumn{1}{c}{ Character } & $\begin{array}{c}\text { Independent } \\
\text { Relative Chances }\end{array}$ \\
\hline Initial odds & $2 \cdot 3333$ \\
Likeness in sex & 0.5000 \\
Likeness in ABO & 0.6113 \\
Likeness in MNS & 0.5000 \\
Likeness in P & 0.9034 \\
Likeness in Rh & 0.5000 \\
Likeness in Kell & 1.0000 \\
Likeness in Lewis & 0.7634 \\
Likeness in Duffy & 0.5000 \\
Likeness in Kidd & 0.5000 \\
Likeness in Xg & 1.0000 \\
Likeness in Dombrock & 1.0000 \\
Likeness in Hp & 1.0000 \\
Likeness in Gm & 1.0000 \\
Likeness in PGM & 0.5000 \\
Likeness in ADA & 0.5000 \\
Likeness in Gc & 0.5000 \\
\hline Difference of total ridge count & 0.2574 \\
Difference of atd angles & 0.5800 \\
\hline Total relative chance (pD) & 0.0006 \\
\hline Total chance (pD/[1 + pD]) & 0.0006 \\
\hline
\end{tabular}

TABLE III

HL-A TYPING OF THE FAMILY

\begin{tabular}{c|c|c|c|c}
\hline Series & Father & Mother & Proposita & Sister \\
\cline { 1 - 2 } $\begin{array}{c}\text { 1st haplotype, } \\
\text { 1st series }\end{array}$ & HL-A9 & HL-A9 & HL-A9 & HL-A9 \\
$\begin{array}{c}\text { 2nd haplotype, } \\
\text { 1st series }\end{array}$ & HL-A9 or X1 & HL-A3 & HL-A9 & HL-A9 \\
$\begin{array}{c}\text { 1st haplotype, } \\
\text { 2nd series }\end{array}$ & Mapi & Mapi & Mapi & Mapi \\
$\begin{array}{c}\text { 2nd haplotype, } \\
\text { 2nd series }\end{array}$ & LND & $\mathbf{R}^{\mathbf{n}}$ & Mapi & Mapi \\
\hline
\end{tabular}

TABLE IV

MIXED LYMPHOCYTE CULTURE (MLC) TEST OF THE TWINS

\begin{tabular}{|c|c|}
\hline 1 & $\begin{array}{l}P+S_{m} \quad \bar{x}=408 \mathrm{rpm} \\
M L C \text { index }=\frac{P+S_{m}}{P+P_{m}}=0.8\end{array}$ \\
\hline 2 & $\begin{array}{l}\mathrm{S}+\mathrm{P}_{\mathrm{m}} \quad \overline{\mathrm{x}}=527 \mathrm{rpm} \\
M L C \text { index }=\frac{S+P_{m}}{S+S_{m}}=1.09\end{array}$ \\
\hline
\end{tabular}

$\mathbf{P}=$ proposita's lymphocytes; $\mathbf{S}=$ twin sister's lymphocytes; $m=$ mitomycin treated cells. 
TABLE V

COAGULATION RESULTS OF THE FAMILY

\begin{tabular}{|c|c|c|c|c|c|c|c|c|}
\hline \multirow{2}{*}{ Tests } & \multicolumn{7}{|c|}{ Members of the Family } & \multirow{2}{*}{ Normal Values } \\
\hline & I.2 & I.3 & I.4 & II. 3 & II. 4 & III.3 & III.4 & \\
\hline Whole blood clotting time (min) & & & 10 & 8 & 7 & 18 & 10 & $7-12$ \\
\hline Bleeding time (sec) & 160 & 120 & 180 & 110 & 140 & 150 & 160 & $60-180$ \\
\hline Thrombocyte count $\left(1000 / \mathrm{mm}^{3}\right)$ & & & 280 & 350 & 280 & 600 & 300 & $150-400$ \\
\hline $\begin{array}{l}\text { In-vitro thrombocyte } \\
\text { adhesiveness }\left(\begin{array}{l}0 \\
0\end{array}\right)\end{array}$ & & & & & & 38 & 25 & $20-50$ \\
\hline Fibrinogen $\left(\mathrm{mg}^{\circ}{ }_{\mathrm{o}}\right)$ & 320 & 380 & 280 & 300 & 250 & 280 & 250 & $200-400$ \\
\hline Prothrombin time (sec) & 16 & 15 & 17 & 16 & 14 & 18 & 17 & $14-18$ \\
\hline Partial thromboplastin time (sec) & 40 & 40 & 42 & 44 & 38 & 68 & 45 & $35-45$ \\
\hline Thromboplastin generation test & Normal & Normal & Normal & Normal & Normal & Delayed & Normal & \\
\hline Factor IX activity $\left(\begin{array}{l}0 \\
0\end{array}\right)$ & & & 44 & 77 & 28 & $<1$ & 15 & $60-160$ \\
\hline
\end{tabular}

the HL-A types given in Table III represent the girls' genotypes.

In the one-way mixed lymphocyte culture (Table IV) the lymphocytes of each twin failed to stimulate those of the other, a fact strongly in favour of monozygotism.

Coagulation Results are summarized in Table V. The prolongation of clotting time and partial thromboplastin time revealed a coagulation disorder in the proposita (III.3).

Deficiency of factor IX in the serum and plasma of the patient was demonstrated by the delayed thromboplastin generation test and by the PTT correction test. The prolonged PTT of the patient's plasma could be shortened by the addition of normal plasma, or normal serum, containing factor IX. On the other hand, $\mathrm{Al}(\mathrm{OH})_{3}$ treated plasma, which does not contain factor IX, and plasma from a patient with severe Christmas disease failed to correct the prolonged clotting time. In this way factor IX deficiency seemed to be verified. Quantitative tests showed that the proposita was completely lacking in factor IX, the activity being below $1 \%$. The diagnosis of Christmas disease was therefore established. Her bleeding time, thrombocyte count and thrombocyte adhesiveness in vitro was found to be normal.

X-linked Genetic Markers. Of the other Xlinked characters studied, G6PD level was normal in both the proposita and her twin sister, and their colour vision was normal.

Chromosome Studies. Analysis of peripheral blood samples of both girls was carried out on 4 occasions. On the first occasion a deletion of the short arm of one of the $\mathrm{C}$ group chromosomes of the proposita was found in 2 out of 10 cells analysed, the other 8 cells were normal 46,XX. On subsequent occasions, however, we found only one more cell with a deleted $\mathrm{C}$ group chromosome out of 50 examined: all other analyses showed normal karyotypes. Thus the original deletion could well have been an artefact in vitro. The karyotypes of the twin of the proposita were normal on all occasions.

In the course of the last study the fluorescence? pattern of the $\mathrm{X}$ chromosomes was found to be normal in both girls.

\section{Discussion}

As shown in Table V, a coagulation disorder was found in the proposita, caused by the lack of factor IX activity in her plasma. As her bleeding time and thrombocyte adhesiveness gave normal, and in the case of platelets, higher than normal values, von Willebrand's disease with factor IX deficiency can be ruled out. That the factor IX level of the proposita is below $1 \%$ could mean either that she cannot produce it or that the substance is produced but is inactive; this question will be subject to further studies.

Routine coagulation tests gave normal results for all other members of the family. The quantitative factor IX assay, however, showed the twin sister of the proposita to have a level of $15 \%$, her mother $28 \%$, and her maternal grandmother $44 \%$. All 3 can be regarded as heterozygotes, their factor levels falling within that range.

There is good evidence that the mean factor values for heterozygotes in haemophilia and Christmas 
disease are considerably lower than the normal values (Rapaport, Patch, and Moore, 1960; Didisheim and Vandervoort, 1962). Frota-Pessoa, Gomes, and Calicchio (1963) found the mean factor IX level for obligatory heterozygotes to be about half that of normal males and females.

The father of our patient had a normal factor IX level of $77 \%$. It seems that the Christmas trait was present in the maternal side of the family for at least the last 3 generations, without ever manifesting itself in a male member. That the father is healthy and has an absolutely normal factor IX level excludes the possibility that the proposita is homozygous for the trait, by straightforward inheritance.

The most curious finding is that, although the twins are identical in all other investigated genetic characters, they give significantly different values for factor IX activity. The factor IX levels of the various members of the family showed no change when re-tested after several months, thus excluding the possibility of an error in determining factor IX activity.

Both twins have $2 \mathrm{X}$ chromosomes, so the disease in the proposita cannot be explained by her being 45,X (Turner's syndrome) as in the cases of Gilchrist, Hammond, and Melnyk (1965) or Bithel, Pizzaro, and MacDiarmid (1970) or 46,XY (testicular feminization syndrome [Nilsson et al, 1959]). The principal assumption is that our patient has inherited a factor IX deficient $\mathrm{X}$ chromosome from her mother, just as her twin sister has. For some reason, however, her other $\mathrm{X}$ chromosome is also incapable of factor IX production.

Why is one twin a heterozygote, while the other gives the signs and laboratory findings of true Christmas disease? During the first chromosome study a deletion of the short arm of a $C$ group chromosome was found in some of the karyotypes examined. If the deletion had involved one of the $\mathrm{X}$ chromosomes this would have offered a rather clear explanation. Namely, that the girl had inherited a factor IX deficient $\mathrm{X}$ chromosome from her mother, and from her father, an $X$ with a deletion involving the factor IX locus and thus preventing it from counteracting the effect of the maternal allele. As we could not confirm this first finding in subsequent cultures, but instead found normal chromosome complements and a normal fluorescent pattern of the $X$, we have to consider other explanations for this puzzling case, though it should be remembered that in spite of the negative chromosome findings, a very faint chance still remains that there is a mosaic deletion: the proportion of mosaicism could be quite different in tissues other than lymphocytes.
The loss of a paternal $\mathrm{X}$ chromosome during cleavage at an early mitotic division with subsequent non-disjunction of the remaining maternal $\mathrm{X}$ chromosome, which bears the gene for Christmas factor, could also be a possible, but not very likely, explanation.

Another theoretically possible, though very unlikely explanation is that a fresh mutation has happened to the plasma thromboplastin component (factor IX) locus of the paternal X of the proposita; this could only have occurred postzygotically, for the twin sister is certainly capable of PTC production, even if at a reduced rate. The mutation could be pictured as happening in an early ancestral cell of the primitive streak from which the proposita was to grow; or perhaps later in a cell which was about to differentiate and give rise to a line normally responsible for factor IX production. The mutation rate at the Christmas disease locus has been estimated to be $(0.55 \pm 0.04) \times 10^{-6}$ by Barrai et al (1968), but this was the rate in gametes-what the somatic cell rate may be is unknown.

It seems to us that the chance of Lyonization, or the subsequent chance migration of Lyonized cells, can best explain the monozygotic twins, one affected with Christmas disease and the other a carrier. According to an investigation at Birmingham (Edwards, 1968) 3 kinds of monozygotic twins can be distinguished, the result of the following mechanisms : (1) the doubling of blastocyst $-28 \%$ of all monozygotic twins; (2) the early doubling of embryonic disc $(61 \%)$, and (3) the late doubling of embryonic disc $(11 \%)$.

Were the twins of the first type their ancestral cells could have separated after the first mitotic division of the zygote and when both lines were subjected by Lyonization it could have happened that in one, by somewhat rare chance, all the paternal Xs carrying the normal allele were inactivated in the cells growing to form the blastocyst, and later the embryonic disc, of the affected twin. In the other cell line inactivation would probably affect nearer the mean expected $50 \%$ paternal and $50 \%$ maternal Xs and the observed carrier would result. This is a simple explanation but, according to Edwards (1968) there is only a $28 \%$ chance that our twins are of this kind.

As $72 \%$ of monozygotic twins are of types 2 and 3 it is more likely that our twins are also of these types. In these instances the chances of Lyonization of paternal or maternal Xs play no part: chance would lie in the migration of cells carrying active or inactive $\mathrm{Xs}$ into the primitive streaks and thence into the embryonic discs growing therefrom.

Whichever type of monozygotic twins they may 
represent the great difference between them, one having Christmas disease and the other not, can most satisfactorily be attributed to the consequences of Lyonization.

\section{Summary}

The case of a 3-year-old girl is presented, who showed severe bleeding tendency and on laboratory investigations was found to have Christmas disease. Her twin sister, who proved to be identical to the proposita on zygosity studies, has never shown any bleeding symptoms. The quantitative factor IX assay, however, showed that the twin sister, as well as the mother and maternal grandmother, are asymptomatic carriers of the disease, while the father is completely healthy. The chromosome complement of the proposita was normal $46, \mathrm{XX}$. A number of explanations for the occurrence of the disease in this girl have been considered: of these, Lyonization and its consequences are thought to be the most probable.

The authors are greatly indebted to Dr R. R. Race and $\operatorname{Dr} \mathrm{R}$. Sanger for their help with blood group determinations and for their most valuable advice with the manuscript. We wish to thank Professor E. KerpelFronius, Professor S. R. Hollán, and Professor J. B. Graham for their helpful suggestions. Special thanks to Professor J. Lindsten for his forthcoming help with the chromosome studies, including fluorescence binding. We are indebted to Dr E. Horváth, Dr P. Nemák, and Dr B Robson for serum and enzyme group analyses, to Dr G. Petrányi, Mr M. Vargha, and Miss K. Ónódy for HL-A determinations and MLC results. Dr M. Dobos and Dr P. Tolnay have kindly reviewed the dermatoglyphic findings. We also thank Dr J. Szélenyi for G6PD determinations, Miss S. Major for colour vision testing, and Miss B. Bogáthy and Miss E. Zahalka for their skilled technical assistance.

\section{REFERENCES}

Barrai, I., Cann, H. M., Cavalli-Sforza, L. L., and Nicola, P. de (1968). The effect of parental age on rates of mutation for haemophilia and evidence for differing mutation rates for haemophilia $A$ and B. American Fournal of Human Genetics, 20, 175-196.
Biggs, R. and Douglas, A. S. (1953). The thromboplastin generation test. Fournal of Clinical Pathology, 6, 23-29.

Bithell, T. C., Pizzaro, A., and MacDiarmid, W. D. (1970). Variant of factor IX deficiency in a female with $45, \mathrm{X}$ Turner's syndrome. Blood, 36, 169-179.

Brecher, G. and Cronkite, E. P. (1950/1951). Morphology and enumeration of human blood platelets. Fournal of Applied Physiology, 3, 365-377.

Caspersson, T., Farber, S, Foley, G. E., Kudynowski, J., Modest, E. J., Simonsson, E., Wagh, U., and Zech, L. (1968). Chemical differentiation along metaphase chromosomes. Experimental Cell Research, 49, 219-222.

Didisheim, P. and Vandervoort, R. L. (1962). Detection of carriers for factor IX (PTC) deficiency. Blood, 20, 150-155.

Edwards, J. H. (1968). The value of twins in genetic studies. Proceedings of the Royal Society of Medicine, 61, 227-229.

Frota-Pessoa, O., Gomes, E. L., and Calicchio, T. R. (1963). Christmas factor: Dosage compensation and the production of blood coagulant factor IX. Science, 139, 348-349.

Gilchrist, G. S., Hammond, D., and Melnyk, J. (1965). Hemophilia in a phenotypically normal female with $\mathrm{XX} / \mathrm{XO}$ mosaicism. New England fournal of Medicine, 273, 1402-1406.

Hellem, A. J. (1960). The adhesiveness of human blood platelets in vitro. Scandinavian fournal of Clinical and Laboratory Investigation, Vol. 12, Suppl., 51.

Langdell, R. D., Wagner, R. H., and Brinkhous, K. M. (1953). Effect of antihemophilic factor on one-stage clotting tests: a presumptive test for hemophilia and a simple one-stage antihemophilic factor assay procedure. Fournal of Laboratory and Clinical Medicine, 41, 637-647.

Lee, R. I. and White, P. D. (1913). A clinical study of the coagulation time of blood. American fournal of Medical Sciences, 145, 495-503.

Marks, P. A. and Gross, R. T. (1959). Erythrocyte-glucose-6 phosphate dehydrogenase deficiency: Evidence of differences between negroes and caucasians with respect to this genetically determined trait. Fournal of Clinical Investigation, 38, 2253-2262.

Maynard Smith, S. M. and Penrose, L. S. (1954/1955). Monozygotic and dizygotic twin diagnosis. Annals of Human Genetics 19, 273-289.

Moorhead, P. S., Nowell, P. C., Mellman, W. J., Battips, D. M., and을 Hungerford, D. A. (1960). Chromosome preparations of leukocytes cultured from human peripheral blood. Experimental Cell Research, 20, 613-616.

Nilsson, I. M., Bergman, S., Reitalu, J., and Waldenström, J. (1959). Haemophilia A in a 'girl' with male sex-chromatin pattern. Lancet, 2, 264-266.

Proctor, R. B. and Rapaport, S. I. (1961). The partial thromboplastin time with kaolin: a simple screening test for first stage plasma clotting factor deficiencies. American fournal of Clinical Pathology, 36, 212-219.

Rapaport, S. I., Patch, M. J., and Moore, F. J. (1960). Antihemophilic globulin levels in carriers of hemophilia A. Fournal of Clinical Investigation, 39, 1619-1625.

Schellekens, P. T. A. and Eujsvoogel, V. P. (1968). Lymphocyte transformation in vitro. Clinical and Experimental Immunology, 3 , 571-584. 